\title{
O, laat er een mis zijn
}

\section{DE AFRIKAANSE LITERATUUR IN NEDERLAND IN 2020}

Het jaar begon met slechte cijfers voor de boekhandel over 2019. Voor het eerst in vijf jaar waren er in Nederland minder boeken verkocht: 40 miljoen exemplaren, dat is $4 \%$ lager. Net als in 2018 was De zeven zussen van Lucinda Riley het meest verkocht. Riley toonde zich met haar Zeven zussen-serie de grote kampioen want in de Top Tien stonden maar liefst vijf Zussenboeken. De nummers 2 en 3 zijn oorspronkelijk Nederlands. Van Grand Hotel Europa, de roman van 547 bladzijden over liefde en massatoerisme van Ilja Leonard Pfeijffer, zijn er 145.000 verkocht. Nummer drie is het betoog van 528 pagina's: De meeste mensen deugen. Een nieuwe geschiedenis van de mens, door Rutger Bregman. Anders dan we misschien dachten is de mens niet altijd en overal geneigd tot alle kwaad, maar is zijn neiging tot het goede sterker. Dit goede nieuws is intussen wijd en zijd vertaald - de verkoop in Nederland in 2019 was 140.000 .

Wat moeten we denken van 2020? Dat is het jaar van de pandemie, ook in de boekenwereld. Vanaf maart heeft het virus de maatschappij gedeeltelijk stilgelegd, ook het culturele leven. De mensen moeten zoveel mogelijk thuisblijven. Voorstellingen en bijeenkomsten, zoals boekpresentaties, werden afgelast of gingen wel door, maar dan met de meeste belangstellenden on-line. Op 15 december 2020 gingen in Nederland alle boekwinkels en bijna alle bibliotheken dicht. Een boekenvriend protesteerde omdat zijn eigen verslaving (aan boeken) kennelijk gevaarlijker werd gevonden dan een verslaving aan alcohol. De slijterijen blijven namelijk open, al is alcoholverkoop na 20 uur verboden.

Om in de sfeer te blijven: zijn de bezorgers nu de kurk waarop de boekhandel blijft drijven? De webwinkels zijn in het algemeen sterk gegroeid - bezorgauto's beheersen het straatbeeld. Zij brengen meestal eten en drinken, maar af en toe ook een boek. De gewone boekwinkel die niet weggeconcurreerd wil worden, gaat zelf ook bezorgen. Een winkel in Leiden krijgt daarvoor hulp van vrijwilligers op de fiets. Hoeveel boeken er op deze manier bij kopers belanden, gaan we nog horen, maar dat er in 2020 minder boeken verkocht maar meer gelezen zijn, lijkt zeker. Want wat kun je thuis beter doen dan lezen? Bij voorkeur Zuid-Afrikaanse boeken natuurlijk.

\section{LEZERS VAN IRMA JOUBERT}

Irma Joubert werd gelezen en verkocht. Van Het meisje uit het verscholen dorp, de Nederlandse vertaling van Mentje, kind van Pas-Opkamp, verscheen in 2020 de zesde druk. En over ander werk van haar kwam in Trouw een lezeres uit Breda aan het woord, een zekere mevrouw Govaert. Tijdens de hittegolf van augustus raakte haar hele gezin met het corona-virus besmet. Daarom moest zij - in een heet huis zonder airco - lang in quarantaine, maar Joubert bracht haar afleiding: "tot diep in de nacht lees ik de trilogie uit ... ik kan niet stoppen met deze historische romans over Zuid-Afrika rond de Tweede Wereldoorlog. Het is nu makkelijk om me in te leven in de Afrikaanse hitte waarin de vrouwelijke hoofdpersonen allen uitzonderlijk moeizaam aan de man komen." 
Al eerder had een andere lezeres van Joubert van zich laten horen. Mevrouw Bles-Bartfeld (90) uit Amstelveen heeft de Nederlandse uitgever opgebeld. Zij had Het meisje uit het verscholen dorp gelezen en in een van de figuren uit het boek zichzelf herkend - zij was namelijk in de jaren veertig een van de ondergedoken kinderen in het Pas-Opkamp geweest. Joubert had niet gedacht ooit nog iemand uit haar boek in levenden lijve tegen te komen. Prompt kwam zij over uit Duitsland om kennis te maken met haar "personage".

\section{DE BIJEENKOMSTEN}

Als jaar voor literaire festivals was 2020 in januari goed begonnen met de Haagse "Winternachten", waarbij Zuid-Afrika, niet voor het eerst, werd vertegenwoordigd door Antjie Krog. Wim Bossema deed kort verslag in de Volkskrant en signaleerde een vraag uit het publiek: hoe moet het Afrikaans loskomen van het verleden als taal van de apartheid? Krog wees erop dat het Afrikaans inmiddels meer donkere sprekers kent dan blanke, en dat getinte schrijvers tegenwoordig baanbrekend werk leveren in een vernieuwend Afrikaans.

Maar vanaf maart keerden de festival-kansen en werd bijna alles onmogelijk. Toen de besmettingscijfers in augustus even gezakt waren, gaf Ria Winters in het Zuid-Afrikahuis in Amsterdam een onderhoudende lezing over Reise met Schoeman, haar boek over haar veelvuldig (maar uitsluitend mail-)contact met Karel Schoeman en over haar reizen naar veel plaatsen waar de schrijver gewoond en gewerkt heeft. Winters heeft me verrast want in de Nederlandse literatuur ken ik geen boek dat lijkt op dit Reise met Schoeman.

De Maatschappij der Nederlandse letterkunde had voor 11 november in samenwerking met hetzelfde Zuid-Afrikahuis een symposium georganiseerd ter herdenking van Elsa Joubert, maar dat moest alweer "digitaal". Een ongezocht voordeel bij die opzet is de kans voor iedereen, waar hij zich maar bevindt, "te land, ter zee, in de lucht of waar ook ter wereld", om het programma te volgen - en dat niet alleen op de tijd van handeling maar ook lang daarna. En sprekers uit de hele wereld kunnen het woord voeren zonder naar Amsterdam te hoeven.

Margriet van der Waal heeft de kneepjes van het digitale vak onder de knie en toonde zich een bedreven presentatrice. Annemarié van Niekerk schetste de overleden schrijfster. De Noordkaapse dichteres Lynthia Julius werkte mee vanuit Bloemfontein. Martina Vitackova, gastprofessor Afrikaanse letteren in Gent, ging met Tycho Maas in afstands-samenspraak over Poppie. Onbetwistbaar hoogtepunt was het gesprek dat Ena Jansen in 2017 met Elsa Joubert had gevoerd in het aftreeoord Berghof in Kaapstad, over oud worden en oud zijn, nog net wel of toch niet meer kunnen schrijven en meer. Het was een passend symposium onder moeilijke omstandigheden, ook een prachtige prestatie van de mensen van het Zuid-Afrikahuis.

De bijdrage van Tycho Maas grijp ik aan voor een stapje terug. In januari $2018 \mathrm{kwam}$ het tijdschrift Armada met een artikel van Maas over Nathan Trantraal: "Alles is nieuw, maar niet veranderd." Als de spreekwoordelijke ezel die geen oude fouten wil herhalen, maak ik nu al melding van Maas' Amsterdamse proefschrift (UvA), hoewel het voor lezers nog niet beschikbaar is (inlichting via t.a.j.maas@uva.nl). Het heet Shifting frameworks for understanding otherness. Daar is geen woord Afrikaans bij, maar Maas gaat wel in op Afrikaanse literatuur, want hij bekijkt het beeld van de Kaapse Khoi zoals dat her en der naar voren komt, onder meer in Eilande van Dan Sleigh. Voor het digitale Zuid-Afrika Spectrum verzorgde Maas van zijn boek in november een samenvatting. 
Datzelfde Spectrum bracht nog veel meer Afrikaanse literatuur. Kirby van der Merwe, de man van Klapperhaar slaap nie stil nie, deed verslag van zijn verblijf in het Karoo Boekehuis in Calvinia: hoe hij daar aan zijn nieuwe boek werkt en hoe hij de afgelopen jaren van die arbeid is afgeleid. In maart besprak Miriam Grootscholten "de nieuwe Deon Meyer", Prooi ("Meyer is er wederom in geslaagd een weergaloos spannende thriller af te leveren"). Later schreef Francine Maessen over haar Leidse MA-scriptie over trauma in Afrikaanse anti-apartheidspoëzie, aan de hand van gedichten van Adam Small, Breyten Breytenbach en Ronelda S. Kamfer. Bijzondere bijdragen kwamen van Riet de Jong-Goossens. Bij haar stuk over de Griekwa-poëzie van Hans du Plessis gaf zij Nederlandse vertalingen van enkele gedichten, waar onder "Boegoe vannie liefde". Later volgde van haar nog een vertaling uit Stormkind van Riana Scheepers.

Als enige bespreekt het Zuid-Afrika Spectrum nieuwe Afrikaanse literatuur die nog niet in het Nederlands vertaald is. Hans Ester besprak de dichtbundel Pleks van plaas van Jerzy Koch. Die verevrou van Jan van Tonder noemde hij: "een rijke roman met een hechte structuur ... gedurfd en geslaagd in de verbinding van het leven in Algerije met dat in de Klein Karoo." Ook vestigde hij de aandacht op Christine Barkhuizen le Roux, als schrijfster ven "toegankelijke romans met grote diepgang". Op haar best vindt Ester haar in het verhaal "Die kersgeskenk" en de roman Getuie.

Ingrid Glorie recenseerde Grensgeval van Marita van der Vyver en wees op felle reacties in Zuid-Afrika omdat Van der Vyver de oorlog in Angola voorstelt als een zinloze onderneming. Van der Vyver heeft het veel beoefende genre van de grensliteratuur volgens Glorie vernieuwd doordat zij niet alleen oog heeft voor een Zuid-Afrikaanse maar ook voor een Cubaanse beleving. Ook prees Glorie de fijnzinnige indrukken van Cuba, eens een paradijs voor uiteenlopende beroemdheden als Hemingway en Sinatra maar nu meer dan ooit in de greep van de armoede, die de revolutie juist had moeten verdrijven. En aan Grensgeval kent zij voorts alle goede eigenschappen toe die werk van Van der Vyver tot "een echte Marita" maken.

Onder de kop: "niemand is cooler as 'n coloured vrou met 'n vuilkyk nie" schreef Glorie over "de nieuwe Kamfer": Chinatown. Over de dichteres luidde het dat "haar woede nog niet is gekalmeerd" en over de bundel: "genadeloos eerlijk, confronterend en provocerend." Glorie herinnerde aan Kamfers complexe verhouding met het Afrikaanse literaire establishment, doordat Kamfer zich blijkbaar van blanke voorgangers moet distantiëren. Kamfers uitgever Podium kondigt intussen de tweetalige Nederlandse uitgave van Chinatown aan, met vertaling door de kersverse PC Hooftprijs-laureaat Alfred Schaffer. 13 april wordt de grote dag.

Over een historische roman met een "prachtig onderwerp": Met die vierkleur in Parys van Renée Conradie Rautenbach, was Glories oordeel genuanceerd: verdienstelijk maar niet helemaal geslaagd. Heel positief was daarentegen haar analyse van Van Heerdens Biblioteek aan die einde van die wêreld. Die bibliotheek komt terug in de kop boven Glories stuk: "bewaarplaats van 'ouderwetse' kunst en literatuur". Zij noemt de roman "niet plot-gedreven maar idee-gedreven" en dat idee is dan de waarschuwing tegen de misvatting, als zou kunst een koloniaal relict zijn dat daarom als een pandemie bestreden moet worden. Tegenover het modieuze denkbeeld dat niemand ooit gekwetst mag worden, handhaaft dit boek - door zijn eigen karakter - het tegenovergestelde inzicht: kunst moet altijd omstreden zijn. Die aanvechtbare kunst is de "ouderwetse" uit de geciteerde kop en tegelijk de enige echte kunst, de kunst waarvoor Van Heerden opkomt. 
2020 bracht ook het slechte nieuws dat Christine Barkhuizen le Roux (1959) plotseling was overleden. De vertaalster Titia van Wulfften Palthe schreef een persoonlijk stuk ter nagedachtenis (december). Palthe heeft Le Rouxs laatste roman, My naam is Prins, ek slaap met die lig aan (2019), net vertaald.

\section{DE VERTALINGEN}

2020, mager jaar, bracht toch nog vertalingen. Een was al in 2019 uitgekomen, het verhaal Danda van Chris Barnard, bij Paolo, het jeugdfonds van de Kampense uitgever Aldo Manuzio (vert. Michiel Angenent, $€ 14,99$ ). Het verhaal speelt in op de traditie van de Hollandse jongens die naar zee gaan. Zuid-Afrikanen herinneren zich de kleine jongen die, op zoek naar zijn vader, op een zelfgemaakt vlot het zeegat uitvaart. Hij belandt natuurlijk in Zuid-Afrika. Danda kreeg een vermelding in het Reformatorisch Dagblad van 17 april 2020.

Agaat van Marlene van Niekerk blijft gevraagd, bij leesclubs en daarbuiten. Bij Querido verscheen de elfde druk ( $€ 20)$. Prooi van Deon Meyer kwam uit als luisterboek, vroeger stok en steun voor de blinde, tegenwoordig vooral voor de automobilist. Maar voor de ware liefhebber is zo'n "audioboek" een zoethoudertje, die hunkert naar zijn nieuwe Meyer. Het antwoord van uitgever Bruna: 23 februari 2021 bij de boekhandel, schrijf maar op, als de winkels dan nog dicht zijn krijgt $u$ het thuisbezorgd.

Twee vertalingen zijn niet alleen aangekondigd maar ook werkelijk verschenen. Bij Manuzio: 1795 van Dan Sleigh (vert. Riet de Jong en Bert Aquarius, € 24,99). Hans Ester noemde dat onder de kop: "Hoe de Kaapkolonie prijsgegeven werd" een "prachtige roman" en een "knappe verbeelding van het boeiende Kaapse leven" (Nederlands Dagblad 21 februari). Maar Wim Bossema toonde zich teleurgesteld. Die vond Stemmen op zee, oftewel Eilande, veel beter: "zo bruisend als de eerste roman was, zo rechtlijnig is $1795 \ldots$ hoofdpersoon William komt, ondanks zijn liefde voor de Franse weduwe Francine-Marie, niet echt tot leven" (de Volkskrant 22 februari).

Hun beider kritieken waren voorafgegaan door een verrassende introductie van 1795 in de vpro-gids door Frank Mulder, met een telefonisch vraaggesprek met Dan Sleigh: "De verkwanselde kolonie" (11-17 januari). Sleigh gaat in tegen de neiging, de geschiedenis te vergeten: "Afrikaners weten niet meer waar ze vandaan komen. Ze willen geen Afrikaans meer leren, alleen nog maar Engels." De machtsovername van de Britten heeft volgens Sleigh alle VOC-geschiedenis "weggepoetst". Hij kiest partij voor de toenmalige kolonisten die de Kaap wilden verdedigen, fel tegen de bestuurders die, op William van Reede na, stemden voor overgave. Zijn roman wil laten zien: "hoe je je vaderland kunt verliezen aan vreemde indringers", iets wat Sleigh tegenwoordig in Zuid-Afrika opnieuw ziet gebeuren, want de regering is zwak en corrupt en "geeft niet om onze bevolkingsgroep." Sleigh zegt geen verhalen meer te zullen schrijven. Jammer! Maar optimist als ik ben denk ik aan een andere Afrikaanse schrijver, van wie na zijn Laaste Afrikaanse boek nog romans en ander werk volgden, zelfs na zijn dood.

Vrijwel tegelijk met 1795 kwam de nieuwe tweetalige bundel van Antjie Krog uit: Broze aarde (vert. Robert Dorsman en Jan van der Haar, Podium € 20). Bij deze bundel in de vorm van kerkelijke missen valt meteen op dat de Afrikaanse ondertitel ("'n Misorde vir die Nuwe Verbond") in het Nederlands de bijbelse connotatie kwijt is: "Een mis voor het universum". In 2019 was deze "mis" al gedeeltelijk te horen op Poetry International, Rotterdam.

Ook Krog gaf een vraaggesprek, aan Vivian de Gier (AD/Algemeen Dagblad plus veel regionale $A D$-kopbladen, 1 februari). De Gier begint met haar eigen standpunt in een bekende 
twist tussen Nederlandse bewonderaars van Krog: "Mooier nog dan haar gedichten lezen is Antjie Krog horen voordragen." Zij schrijft Krog ook het vermogen toe, afstanden te overbruggen tussen "landen, volkeren, huidskleuren en maatschappelijke klassen." Krog zelf spreekt over de actualiteit van de filosofie van Afrika, met "onderlinge verbondenheid" als "grondbeginsel." Ook zijn mens en natuur in Afrika eerder één, terwijl de westerse mens tegenover de natuur staat. Samenvattend: "als mens zijn we afhankelijk van elkaar en van de natuur." De mis-vorm heeft zij gekozen om het new age-achtige, dat dreigt zodra je over de natuur praat, te vermijden. "Oude Bijbelse gezangen" brengen eerder de sfeer die zij wilde. De Gier: maar schrikken die gezangen niet af? Daar is Krog niet bang voor want "niet-religieuze mensen" blijken er juist goed op te reageren.

In een vermelding van Broze aarde begon ook Ariejan Korteweg over Krogs "intense, bezwerende voordracht" (de Volkskrant 1 februari). We vinden die ook terug in een bevlogen recensie van Dieuwertje Mertens: "O, laat er een mis zijn waar Krog de voorganger is. De nagalm van haar stem dwingt zelfs ongelovigen op de knieën. Een diepreligieuze poging alles te omvatten in gretig doortastende taal" (Het Parool 1 februari). Ook Janita Monna vindt het schitterende poëzie. De woorden dragen een "overdonderende kracht, door de muziek, die, met dank aan de voortreffelijke vertalers, ook in het Nederlands blijft." Zij hoopt op opvoering "in een kerk, een theater, in een park" (Trouw 28 maart).

$\mathrm{Na}$ al deze welsprekende bijval schreef Rien van den Berg een paar maanden later vanuit christelijk standpunt de belangrijkste kritiek. Hij kent de grote rol van religie in Krogs werk en vat Broze aarde op als een "echte" mis, geschreven om te functioneren in een religieuze setting. Zo kwam hij tot zijn eerste indruk: dit is blasfemie. Maar Krogs godslastering ervoer hij tegelijk als imponerende poëzie, als "bovensteplankpoëzie" zelfs. De criticus bleef verscheurd. De gedichten waren prachtig maar ook: "bij vlagen ongenietbaar", doordat bij Krog het universum geen beeld voor God is maar doordat zij dit omdraait: "God is een beeld voor het universum." Van den Berg besloot met een snedige herhaling van wat hem dwars zit: "Krog probeert ons eerbied voor de schepping bij te brengen. Maar de eerbied voor de Schepper sneuvelt." ("Gloria in Excelsis Soli”, Nederlands Dagblad 26 juni). Voelde Krog in het gesprek met De Gier al aan dat de waardering voor haar werk bij "niet-religieuze mensen" juist minder problematisch ligt dan bij gelovigen?

\section{INGRID JONKER EN ANNE VEGTER}

Anne Vegter (1958) wordt gerekend tot de belangrijkste Nederlandse dichters. Zij debuteerde met kinderboeken en kreeg meteen de Woutertje Pieterse-prijs. Later werden ook haar poëzie en toneelstukken bekroond. In 2013-'17 was zij Dichter des Vaderlands.

In het poëzietijdschrift Het Liegend Konijn stond van haar in 2013 een reeks "Hoe Europa doen", een monoloog met aan het woord Ingrid Jonker. Die monoloog vormt nu de opening van haar bundel Big data (Querido, € 16,99), drie variaties op het thema van de verlaten geliefde. In elk deel lezen we over een in de steek gelaten vrouw. "Jonker" vertelt over haar bekende mislukte Europa-reis in 1964 en over haar halfhartige minnaars Jack Cope en André Brink. In het tweede deel lijkt Vegter zelf de verlatene. In Het Parool en het Dagblad van het Noorden (30 augustus, 4 september) vertelde zij aan interviewster Dieuwertje Mertens hoe zij in 2017 zelf "gedumpt" werd en achtergelaten met twee kinderen. Het laatste deel, "Medea 2.0", is verreweg het felst. Zoals men weet is Medea, tovenares en heks in de Griekse mythologie, sinds het drama van Euripides (480-406) ook de klassieke verlaten vrouw en vooral de klassieke verpersoonlijking van de wraak. Zij vermoordde haar mededingster en 
maakte haar eigen kinderen dood om haar weggelopen man kinderloos te maken. Het keert bij Vegter terug.

Big data kreeg veel lof. Hanneke de Klerck vindt het mooi dat Vegter ondanks alle woede en verdriet toch zorgt voor "een zekere humor en monterheid". Uit "Hoe Europa doen" citeert De Klerck, als mooi terzijde van Vegters Ingrid: "Ik heb geen probleem met twee mannen. / Maar twee mannen hebben geloof ik wel altijd een probleem met één vrouw." Zij wijst ook op een derde man die Ingrid in de steek heeft gelaten: haar vader (de Volkskrant 28 augustus). Janita Monna beschrijft Big data als voorbeeld van literatuur die verdriet, woede en wraakzucht overwint in de bewoording: "De taal prikt en streelt, is helder en vervreemdend. Pijn werd poëzie." (Trouw 30 augustus).

In de - grote - waardering van Alfred Schaffer blijft het Jonker-stuk wat achter bij de andere twee, al vindt hij daar wel een opvallend "lekkere zin": "O mijn vadertje was zooooooooooo bang voor reputatieverlies yo, yo, yo" (De Groene Amsterdammer 17 september). Voor Obe Alkema is zo'n verschil er niet, hij vindt alle delen prachtig. Omdat Ingrid Jonker de zee inliep, moet Vegters vereenzelviging met haar uiteindelijk mislukken, maar dat maakt "Hoe Europa doen" juist "ontzagwekkend." Vegter is hier volgens Alkema op haar onverschrokkenst (NRC 15 januari 2021).

Ieder apprecieert op zijn eigen manier, maar het staat wel vast dat Anne Vegter met haar Big data dit jaar zorgde voor de verrassendste verschijningsvorm van de Afrikaanse literatuur in Nederland.

\section{EEP FRANCKEN}

Universiteit Leiden en Noordwes-Universiteit

E-pos: a.a.p.francken@hum.leidenuniv.nl 